\title{
THE COVID-19 PANDEMIC AND STRUCTURAL BARRIERS FOR MIGRANT AGRICULTURAL WORKERS IN ONTARIO
}

\author{
THERESA JAMES *
}

\section{INTRODUCTION}

During the summer of 2020 after the peak of the first wave of the COVID-19 pandemic, some regions in southern Ontario lagged behind others in moving to the next stage of the provincial government's reopening plan. ${ }^{1}$ Daily government updates on pandemic-related restrictions highlighted the reasons why these regions remained COVID-19 hotspots. Significant outbreaks on farms, particularly among migrant farm workers, led to hundreds of infections and several deaths. ${ }^{2}$ This garnered widespread public attention to migrant agricultural workers' particular vulnerability to the virus.

This paper aims to explore the ways in which COVID-19 has exposed longstanding shortcomings in labour and immigration law protections for migrant farm workers in Canada, thereby exacerbating their already precarious economic and immigration status. It also highlights the ways in which government responses to this group's increased vulnerability in the form of policy and legislative measures have been inadequate. While migrant workers across different industries and sectors face many of

Copyright $(0) 2021$ by Theresa James.

* Theresa James completed her Juris Doctor (JD) and Bachelor of Civil Law (BCL) at McGill University's Faculty of Law in 2021. She previously received her Honours Bachelor of Social Sciences (BSocSc) in Conflict Studies and Human Rights from the University of Ottawa. The author wishes to thank Professor Adelle Blackett for her support and guidance in preparing an earlier version of this paper, as well as the editors of the Western Journal of Legal Studies for their invaluable comments and feedback.

${ }^{1}$ See Government of Ontario, "Windsor-Essex Remains in Stage 2" (4 August 2020), online: $<$ https://news.ontario.ca/en/release/57876/windsor-essex-remains-in-stage-

2> [https://perma.cc/DQ5E-C478]. See also Government of Ontario, "Ontario Takes Immediate Action to Stop COVID-19 Outbreaks in Windsor-Essex" (4 June 2020),

online: $<$ https://news.ontario.ca/en/release/57366/ontario-takes-immediate-action-to-stop-covid-19outbreaks-in-windsor-essex> [https://perma.cc/8E2W-9YQD]; Government of Ontario, "Businesses and Services to Reopen in Windsor-Essex, with Exceptions: Ontario Holds Back Leamington and Kingsville due to Higher Rates of COVID-19" (24 June 2020),

online: $<$ https://news.ontario.ca/en/release/57374/businesses-and-services-to-reopen-in-windsor-essexwith-exceptions> [https://perma.cc/NU2X-ZZVL].

${ }^{2}$ See e.g. Jasmine Pazzano, "Coronavirus: Canada's migrant farm workers face fatal COVID-19 outbreaks, alleged mistreatment", Global News (28 August 2020), online:

$<$ https://globalnews.ca/news/7301324/coronavirus-canadas-migrant-farm-workers-alleged-mistreatment/> [https://perma.cc/6TTS-WW38]; see also Nicole Bogart, “ Advocates demand Ontario shut down farms as COVID-19 cases soar among workers", CBC News (29 June 2020), online:

$<$ https://www.ctvnews.ca/health/coronavirus/advocates-demand-ontario-shut-down-farms-as-covid-19cases-soar-among-workers-1.5004897?cache=yes\%3FclipId\%3D1691853> [https://perma.cc/LW5R$3 \mathrm{XTS}]$. 
the same barriers and vulnerabilities, this paper focuses on the particular challenges confronted by agricultural labourers working under the Seasonal Agricultural Workers Program ("SAWP") in Ontario. Structural problems in the immigration and labour regimes prevent migrant workers under the SAWP from freely exercising their rights on an equal basis with other workers. These problems render SAWP workers particularly vulnerable to exploitation and harm during both pandemic and non-pandemic times. Echoing longstanding calls for change from workers and their advocates, this paper argues that more systemic change is necessary to fix these structural deficiencies. It suggests that there is now unprecedented urgency and opportunity to end systemic barriers in both the labour and migration spheres.

This paper proceeds as follows: Part I introduces the SAWP structure. Part II explores the existing barriers in labour and employment law for agricultural migrant workers in Ontario and the effects of COVID-19 on these barriers. Part III then examines the immigration dimension of these challenges. Although the labour and immigration dimensions are necessarily intertwined, they are addressed separately to allow a thorough deconstruction of the legal regimes at play, with labour and employment law governed by provincial legislation and the federal government responsible for the SAWP and associated immigration regulation. Other key areas, including housing and health care, are also discussed as they relate to employment and immigration status. These sections demonstrate that minor, isolated legislative and policy responses to COVID-19 outbreaks among SAWP workers are not sufficient, and that much deeper, systemic changes are needed to address migrant workers' vulnerabilities. Finally, Part IV explains the heightened urgency and potential opportunity for deeper structural change to protect the rights of migrant agricultural workers. This section explores how the pandemic has brought public attention to the plight of migrant farm workers and provoked broader public discussions about how societies and economies can be structured in a more equitable and sustainable way.

\section{THE SEASONAL AGRICULTURAL WORKER PROGRAM (SAWP)}

The SAWP was established through a Memorandum of Understanding ("MOU") between Canada, Mexico, and ten Caribbean states. ${ }^{3}$ It is administered according to a set of operational guidelines and individual employment agreements. The MOU is characterized as an "intergovernmental administrative arrangement" rather than as a binding treaty under international law - a characterization which removes the program

\footnotetext{
${ }^{3}$ Memorandum of Understanding Between the Government of the United Mexican States and the Government of Canada Concerning the Mexican Seasonal Agricultural Workers Program, 27 April 1995, art 2(c) (entered into force retroactively 1 January 1995), cited in Cruz-Lopez, Irma Fabiola, Seasonal Agricultural Workers Program: Looking at Mexican Participation Through a Magnifying Glass, (PhD Thesis, University of Ottawa Faculty of Law, 2013) [unpublished] at 338-39.
} 
from the arguably more transparent and enforceable sphere of legally binding treaties. The MOUs and related operational guidelines are negotiated and established by the government parties. The SAWP allows Canadian employers to hire Temporary Foreign Workers ("TFWs") for a period of up to eight months to work on farms in specific agricultural commodity sectors. Crucially, SAWP workers, like many TFWs in other industries, have closed work permits, binding them in a contractual employment relationship to a specific employer.

In 2018, nearly 20 percent of agricultural jobs in Canada and over 30 percent in Ontario were filled by temporary foreign workers from the SAWP and the Agricultural Stream of the Temporary Foreign Worker Program ("TFWP"). ${ }^{4}$ In recent years, this has added up to over 40,000 temporary foreign agricultural workers employed in Canada annually, the vast majority of whom are SAWP participants..$^{5}$ Given the substantial number and proportion of temporary foreign workers in Ontario's agricultural sector, SAWP-related employment and immigration policies affect a large cohort of critical essential workers in Ontario and across Canada.

\section{LABOUR/EMPLOYMENT LAW DIMENSION OF MIGRANT FARM}

\section{WORKER VULNERABILITY}

\section{a) Employment Standards Legislation}

On paper, migrant farm workers in Ontario have many of the same rights and protections under employment law as farm workers who are Canadian citizens or permanent residents. However, agricultural workers as a whole are subject to many important exclusions. Further, in practice, migrant workers face many barriers to exercising their legal rights due to their vulnerable status and the precarious nature of farm work.

\section{i. Exemptions from Employment Standards for Agricultural Workers}

Ontario's Employment Standards Act, 2000 ("ESA") ${ }^{6}$ establishes minimum standards for employees in relation to many core aspects of the employment relationship. However, a regulation under the ESA, When Work Deemed to be Performed, Exemptions and Special Rules, ${ }^{7}$ excludes a wide range of farm workers from certain employment standards such as hours of work, hours free from work, eating periods, overtime pay,

\footnotetext{
${ }^{4}$ Statistics Canada, "COVID-19 Disruptions and Agriculture: Temporary Foreign Workers" (17 April 2020), online: <https://www150.statcan.gc.ca/n1/pub/45-28-0001/2020001/article/00002-eng.htm> [https://perma.cc/42AH-Q4ZY].

${ }^{5} \mathrm{Ibid}$.

${ }^{6}$ RSO 2000, c 41 [ESA].

${ }^{7}$ O Reg 285/01 [Exemptions].
} 
minimum wage, and vacation with pay. Specifically, these provisions of the ESA do not apply to persons employed on a farm whose work is directly related to the primary production of a range of designated agricultural products. ${ }^{8}$ There are also specific rules that apply to employees working on a farm to harvest fruit, vegetables or tobacco for marketing or storage. For example, these workers are generally entitled to be paid the equivalent of minimum wage. However, if the employer compensates the employees on an appropriate piece work rate basis or deducts certain costs for providing employees with room and board, the employer will be "deemed" to pay minimum wage, even if the actual wage paid is less than the minimum. ${ }^{9}$ Furthermore, like the other types of farm workers listed above, these workers are not entitled to limits on hours of work, rest periods, eating periods, or overtime pay. ${ }^{10}$

While on the surface the exemptions mentioned above apply to all farm workers regardless of migration status, in practice, they largely affect non-Canadian labourers such as those working under the SAWP. This is because Canada's agricultural workforce has been increasingly made up of migrant workers in recent years. ${ }^{11}$

\section{ii. Employment Contracts}

These exclusions from basic employment standards are operationalized through standard form employment contracts between employers and SAWP participants. For example, the 2020 contract for SAWP workers from the Caribbean allows for workers' hours to be extended "when the situation requires it, and where the conditions of employment involve a unit of pay". ${ }^{12}$ Despite the clause also providing that "workers must not be required to work excessive hours that would be detrimental to their health or safety", ${ }^{13}$ this vague threshold for limiting excessive hours of work contrasts sharply with the prescribed limits on daily and weekly hours of work in section 17 the ESA. While that same provision of the SAWP contract stipulates that additional hours of work shall respect applicable provincial labour laws and give the same rights to Caribbean workers as to Canadian workers, ${ }^{14}$ this assurance loses much of its meaning when the provincial

\footnotetext{
${ }^{8}$ Ibid, s 2(2).

${ }^{9}$ Ibid, ss 24-25.

${ }^{10}$ With the exception of certain seasonal employees involved in canning, processing, and packing fresh fruits or vegetables, who are entitled to overtime pay for working over 50 hours per week: ibid, $\mathrm{s} 15$.

${ }^{11}$ See University of California, "Canada's Seasonal Workers Program (SAWP)", Rural Migration News (20 December 2019), online: <https://migration.ucdavis.edu/rmn/blog/post/?id=2372> [https://perma.cc/U8BF-5Q2J].

${ }^{12}$ Employment and Social Development Canada, Contract for the Employment in Canada of Commonwealth Caribbean Seasonal Agricultural Workers - 2021 (Ottawa: ESDC, 2020), online: Government of Canada $<$ https://www.canada.ca/en/employment-social-development/services/foreignworkers/agricultural/seasonal-agricultural/apply/caribbean.html> [https://perma.cc/8E6P-PU7X], s I(5) [SAWP Contract-Caribbean].

${ }_{13}^{13}$ Ibid.

${ }^{14}$ Ibid.
} 
legislation itself pre-emptively excludes agricultural workers under the SAWP from core employment standards protections.

These legislated exemptions represent disastrous barriers for the protection of minimum standards in the context of employment relationships governed by private contractual arrangements. A key protection against exploitative contractual provisions is the prohibition against contracting out of minimum legislated employment standards. ${ }^{15}$ However, this protection is meaningless once the legislation itself excludes workers from these protections. Thus, the legislated exclusion of many farm workers from key employment standards reflects a systemic marginalization of agricultural workers, who are disproportionately migrants.

The lack of legislative and contractual protections for migrant workers became even more apparent because of COVID-19, particularly in relation to housing conditions. SAWP workers have no control over their housing conditions because they generally stay in employer-provided housing. Their employment contracts stipulate that the employer must provide the worker with "clean, adequate living accommodations" that meet provincial requirements. ${ }^{16}$ However, the reality is much different. SAWP workers typically live in overcrowded bunkhouses with serious cleanliness and sanitation problems. A 2014 report found that over half of complaints from Mexican migrant workers about unsafe working conditions related to poor housing conditions with reports of snakes, rats, and bedbugs in their accommodations. ${ }^{17}$ There are no national housing standards for migrant farm workers in Canada, despite advocacy for such standards to be adopted. ${ }^{18}$

\section{iii. Other Legislated Protections for Migrant Workers}

Migrant agricultural workers in Ontario also have the same rights as other employees under other provincial legislation. Employers have an obligation to take every reasonable precaution to protect the health and safety of workers as prescribed by the

\footnotetext{
${ }^{15}$ ESA, supra note 6, s 5.

${ }^{16}$ Employment and Social Development Canada, Contract for the Employment in Canada of Seasonal Agricultural Workers from Mexico -2020 (Ottawa: ESDC, 2020), online: Government of Canada $<$ https://www.canada.ca/en/employment-social-development/services/foreignworkers/agricultural/seasonal-agricultural/apply/mexico.html> [https://perma.cc/3JWM-6JX4], s II(1) [SAWP Contract - Mexico]; SAWP Contract - Caribbean, supra note 12, s II(1).

${ }^{17}$ See Sara Mojtehedzadeh, "Snakes, rates, bedbugs, abuse. Complaints filed by Mexican migrant workers expose underside of Canada's seasonal agriculture program", Toronto Star (4 October 2019), online: <https:/www.thestar.com/news/canada/2019/10/14/snakes-rats-bedbugs-abuse-complaints-filedby-mexican-migrant-workers-expose-underside-of-canadas-seasonal-agriculture-program.html> [https://perma.cc/LXQ6-5JLV].

${ }^{18}$ See Migrant Workers Alliance for Change, "Unheeded Warnings: COVID-19 \& Migrant Workers in Canada", $M W A C$ (June 2020), online (pdf): <https://migrantworkersalliance.org/wpcontent/uploads/2020/06/Unheeded-Warnings-COVID19-and-Migrant-Workers.pdf > [https://perma.cc/R88Y-AF3V] [MWAC].
} 
Occupational Health and Safety Act. ${ }^{19}$ In addition, Ontario's Employment Protection for Foreign Nationals Act, $2009^{20}$ provides certain additional employment protections for migrant workers in Ontario who are working under a government program. The EPFNA formally prohibits certain practices that exploit migrant workers, including recruitment agencies charging fees to migrant workers, employers seizing migrant workers' property and legal documents, and reprisals against workers who ask about their rights under the $E P F N A .^{21}$ It also lays out a complaint mechanism and framework for offences and prosecutions. $^{22}$

Employees also have the right not to face discrimination based on prohibited grounds (including race, ancestry, colour, ethnic origin, and citizenship) in their employment under Ontario's Human Rights Code. ${ }^{23}$ There have been some human rights cases in Ontario and other provinces where racialized migrant farm workers have alleged discrimination with respect to their employment and related services under the Code. ${ }^{24}$ However, the Code has been interpreted narrowly in the context of migrant workers thus far in practice. For example, in Peart v Ontario (Community Safety and Correctional Services), a Jamaican worker under the SAWP died while working at a tobacco farm after a 1,000-pound tobacco bin toppled onto him. ${ }^{25}$ Despite advocacy for an investigation into his death, an inquest was denied. An application was brought before the Human Rights Tribunal of Ontario ("the Tribunal") where the applicants argued that section 10(5) of the Coroner's $A_{c t}{ }^{26}$ discriminated against SAWP workers on the basis of race, ethnic origin, and citizenship, contrary to the Code. ${ }^{27}$ This provision of the Coroner's Act required mandatory inquests into deaths of workers in the construction and mining industries, but not in the agricultural industry. ${ }^{28}$ The Tribunal recognized the racialization and vulnerability of SAWP workers ${ }^{29}$ and found that the provision of the Coroners Act had a disproportionate impact on this group, but that this impact did not create "a disadvantage by perpetuating prejudice or stereotyping" or result in substantive inequality for the

\footnotetext{
${ }^{19}$ RSO 1990, c O1, s 25(2)(h) [OHSA]. Note some limited exceptions for farming operations: see Farming Regulations, O Reg 414/05. See also Ontario, Ministry of Labour, "Guide to the Occupational Health and Safety Act for farming operations" (last modified 21 February 2020), online:

$<$ https://www.ontario.ca/page/guide-occupational-health-safety-act-for-farming-operations\#section-4> [https://perma.cc/6ECT-KP33].

${ }^{20}$ SO 2009, c 32 [EPFNA].

${ }^{21}$ Ibid, ss 7-10.

${ }^{22}$ Ibid, ss 20, 41-48.

${ }^{23}$ RSO 1990, c H 19, s 5 [Code].

${ }^{24}$ See e.g. Hosein v Ontario (Community Safety and Correctional Services), 2018 HRTO 298; N(P) $v$ $R(F), 2015$ BCHRT 60; Québec (Commission des droits de la personne \& des droits de la jeunesse) $c$ Centre Maraîcher Eugène Guinois Jr inc, 2005 CarswellQue 1329 (QCTDP).

252014 HRTO 611 at para 8 [Peart].

${ }^{26}$ RSO 1990, c 37.

${ }^{27}$ Peart, supra note 25 at para 1.

${ }^{28}$ Supra note 26, s $10(5)$.

${ }^{29}$ Peart, supra note 25 at para 273.
} 
workers, when considering the context and purpose of the provision. ${ }^{30}$ This decision demonstrates the difficulty in ensuring employer accountability for the risks that SAWP workers face due to their working conditions.

\section{iv. Enforcement of Labour Standards}

Another related issue is that despite the rights to which migrant workers are entitled on paper, migrant farm workers face many barriers to exercising them in practice. Even when complaints are successfully made, the nature of the remedies available to migrant workers are often ineffective. The most likely consequence for an employer found to have violated the $E S A$ is an order to comply and pay workers what they are owed, as penalties are very rarely ordered. ${ }^{31}$ However, this remedy fails to incentivize employers to comply with the law in the first place. The compensation-based remedies available are also unlikely to address SAWP workers' concerns regarding longer-term employment security. ${ }^{32}$

Until 2018, under Ontario's reactive, complaints-based model for enforcing employment standards, employees were required to contact their employer before filing a formal complaint, with exceptions for vulnerable workers. According to one study, a relatively high proportion of agricultural workers who filed complaints did not contact their employers out of fear of retaliation. ${ }^{33}$ Despite the anti-reprisal provision in the $E S A,{ }^{34}$ it has long been acknowledged that migrant workers, particularly migrant farm workers, are often reluctant to make formal complaints due to fear of reprisals and the potential consequences for their legal status and ability to continue working in Canada. ${ }^{35}$ Although the requirement to contact one's employer before filing a complaint has since been removed, workers may still fear reprisal if they are unaware that this rule has changed. Indeed, lack of awareness of one's rights is another reason why workers choose not to bring forward complaints. ${ }^{36}$

This concern about reprisals stems from the fact that SAWP workers' (and other TFWs') work permits are tied to a single employer through a bonded employment relationship, prohibiting them from leaving one employer to work for another. ${ }^{37}$ This

\footnotetext{
${ }^{30}$ Ibid at paras 288-89, 345.

${ }^{31}$ See Leah F Vosko et al, "Enforcing Employment Standards for Temporary Migrant Agricultural Workers in Ontario, Canada: Exposing Underexplored Layers of Vulnerability" (2019) 35:2 Intl J of Comp Lab L \& Ind Rel 227 at 241.

32 See Bethany Hastie, "The Inaccessibility of Justice for Migrant Workers: A Capabilities-Based Perspective" (2017) 34:2 Windsor YB Access Just 20 at 36-37.

${ }^{33}$ Vosko, supra note 31 at 239-40.

${ }^{34}$ Supra note 6, s 74.

${ }^{35}$ See Vosko, supra note 31 at 239-49. See also Sarah Marsden, "Assessing the Regulation of Temporary Foreign Workers in Canada” (2011) 49:1 Osgoode Hall LJ 39 at 52; Hastie, supra note 32 at 35.

${ }^{36}$ See Vosko, supra note 31 at 240.

${ }^{37}$ Hastie, supra note 32 at 36.
} 
places the migrant worker in a drastically different position than a Canadian worker who could make a formal complaint and still seek potential employment elsewhere. There is a much greater power imbalance in the employer-employee relationship for migrant workers, who depend on their current employer not only for their income in the short term, but their legal status in the country and their ability to gain income in the future. ${ }^{38}$ For this reason, the anti-reprisal provision in the ESA is extremely ineffective for SAWP workers in practice.

\section{b) Labour Law Protections}

Agricultural workers have also historically been excluded from Ontario's statutory labour protections even as other provinces have included farm workers in their respective labour relations regimes to some extent. ${ }^{39}$ Although they were granted a statutory path to collective bargaining in 1994 through the Agricultural Labour Relations Act, $1994,{ }^{40}$ the newly-elected Harris government repealed this legislation in 1995. Prior to 2002, section 3(b) of Ontario's Labour Relations Act, $1995^{41}$ excluded agricultural workers from important protections in the statute such as the freedom to organize, protections against employer interference with trade union activity, and employer intimidation and coercion.

This exclusion was successfully challenged by individual farm workers and union organizers in Dunmore v Ontario (Attorney General). ${ }^{42}$ The Supreme Court of Canada ("SCC") held that the total exclusion of agricultural workers from the $L R A^{43}$ violated the section 2(d) right to freedom of association under the Canadian Charter of Rights and Freedoms, ${ }^{44}$ finding that the absence of statutory protection impeded their ability to establish, join and maintain an agricultural employee association. ${ }^{45}$

However, in response to Dunmore, the Ontario government enacted the Agricultural Employees Protection Act, 2002, ${ }^{46}$ creating a separate labour relations regime with fewer rights for farm workers than those available under the $L R A$, while maintaining their exclusion from the $L R A$ under section 3(b.1). This new legislation was subsequently challenged by workers in Fraser $v$ Ontario (Attorney General) ${ }^{47}$ for allegedly violating their right to freedom of association under section 2 (d) of the Charter.

\footnotetext{
${ }^{38}$ See Marsden, supra note 35 at 51.

${ }^{39}$ See Fraser v Ontario (Attorney General), 2011 SCC 20 at para 1 [Fraser].

${ }^{40}$ SO 1994, c 6, as repealed by Labour Relations Act, 1995, SO 1995, c 1, Schedule A.

${ }^{41}$ SO 1995, c 1, Schedule A, ss 3(b), 5, 70, 76 [LRA].

422001 SCC 94 at para 206 [Dunmore].

${ }^{43}$ LRA, supra note 41.

${ }^{44}$ Part I of the Constitution Act, 1982, being Schedule B to the Canada Act 1982 (UK), 1982, c 11 [Charter].

${ }^{45}$ Dunmore, supra note 42 at paras 67-68.

${ }^{46}$ SO 2002, c 16 [AEPA].

${ }^{47}$ Fraser, supra note 39.
} 
In Fraser, the SCC held that the AEPA did not breach section 2(d) of the Charter ${ }^{48}$ This is because the statute still provided a process for employee associations to make representations to employers, and protected the right to have employers consider these representations in good faith. ${ }^{49}$ In the SCC's view, these protections were sufficient to protect the right to collective bargaining and therefore the freedom of association. ${ }^{50}$

In Fraser, the SCC backtracked from an earlier decision in which the Court found that collective bargaining is part of the freedom of association. ${ }^{51}$ This earlier finding was grounded on an interpretation of international labour law, specifically the Freedom of Association and Protection of the Right to Organize Convention, ${ }^{52}$ which Canada has ratified. The effect of Fraser was to raise "the threshold for finding a violation of freedom of association ... and [water] down the right to bargain collectively". ${ }^{53}$ As stated by Judy Fudge, "Fraser signal[ed] a narrowing of the scope of workers' collective activities protected under the Canadian constitution". 54

Although a more expansive interpretation of the freedom of association was subsequently adopted by the SCC, ${ }^{55}$ a recent decision by the Ontario Agriculture, Food and Rural Affairs Appeal Tribunal in $U F C W v$ MedReleaf ${ }^{56}$ circumscribed this expansion in the agricultural industry and affirmed the narrower approach in Fraser. In MedReleaf, the United Food and Commercial Workers International Union ("UFCW") claimed that the APEA violated the section 2(d) Charter rights of agriculture workers and argued that Fraser's authority needed to be re-examined in light of the constitutional recognition of the right to strike. ${ }^{57}$ The Agriculture, Food and Rural Affairs Appeal Tribunal held that the $A P E A$ did not violate section 2(d) because it did not "substantially [interfere] with a meaningful process of collective bargaining." 58 The tribunal further interpreted the holding in Fraser to mean that, read in light of other recent cases, a labour relations scheme will only violate section 2(d) if it "contains an outright ban on strikes without providing an alternative statutory dispute resolution mechanism". ${ }^{59}$ The tribunal also rejected the UFCW's claim that the constitutional right to strike requires statutory job

${ }^{48}$ Ibid at paras $106-07$.

${ }^{49}$ Ibid.

${ }^{50}$ Ibid.

${ }^{51}$ Health Services and Support-Facilities Subsector Bargaining Assn v British Columbia, 2007 SCC 27 at para 86 .

529 July 1948, 68 UNTS 17 (entered into force 4 July 1950, accession by Canada 23 March 1972).

${ }^{53}$ Judy Fudge, "Constitutional Rights, Collective Bargaining and the Supreme Court of Canada: Retreat and Reversal in the Fraser Case" (2012) 41:1 Indus LJ 1 at 23.

${ }^{54}$ Ibid at 28-29.

${ }^{55}$ See Mounted Police Association of Ontario v Canada (Attorney General), 2015 SCC 1 at paras 67, 74-80; Saskatchewan Federation of Labour v Saskatchewan, 2015 SCC 4 at paras 51, 75, where the majority recognized a constitutional right to strike.

${ }^{56}$ UFCW v MedReleaf Phase 2, 2020 ONAFRAAT 8 [MedReleaf].

${ }^{57}$ Ibid at para 39.

${ }^{58}$ Ibid at para 114.

${ }^{59}$ Ibid at para 94. 
protections for workers exercising that right. ${ }^{60}$ It noted that the agricultural labour shortages and time-sensitive nature of agricultural work gives farm workers economic leverage with their employers and that the $A E P A$ does not diminish this economic power. ${ }^{61}$ In reaching its conclusion, the tribunal emphasized a single anecdotal case of a collective agreement negotiated by migrant farm workers in the United States in the absence of a statutory framework. ${ }^{62}$ Meanwhile, the tribunal failed to recognize the effect of migrant workers' precarious migration status in Canada on their ability to exercise their rights without full statutory protections.

The decisions in Fraser and MedReleaf highlight the "invisibility of Ontario's agricultural workers" and "farm worker exceptionalism under the law". ${ }^{3}$ This exceptionalism and exclusion from a statutory collective bargaining scheme exacerbates the existing vulnerabilities of migrant farm workers, which became more evident during the pandemic. ${ }^{64}$

Given the high proportion of migrant workers in Ontario's agricultural sector, the lack of labour protections for agricultural workers has a discriminatory impact on those workers who are migrants, contrary to Article 6.1 of the International Labour Organization's Migration for Employment Convention (Revised), $1949 .{ }^{65}$ Despite the SCC's reluctance to address section 15 claims of discrimination based on occupational status in decisions like Dunmore and Fraser, the exclusion of agricultural workers, largely migrants, from equal labour protections constitutes a clear form of adverse-impact discrimination on the basis of nationality and race.

\section{c) Effect of COVID-19}

\section{i. Health, Housing and Working Conditions}

The COVID-19 pandemic has both exposed and exacerbated the existing structural barriers for migrant farm workers caused by a lack of employment and labour law protections. Particularly striking is the combined effect of the virus and the poor housing conditions for SAWP workers discussed above. The "relative economic insecurity" of these workers compelled them "to resort to living in overcrowded,

\footnotetext{
${ }^{60}$ Ibid at para 97.

${ }^{61}$ Ibid at para 100.

62 Ibid at para 131.

${ }^{63}$ Adrian Smith, "Racialized in Justice: The Legal and Extra-Legal Struggles of Migrant Agricultural Workers in Canada" (2013) 31:2 Windsor YB Access Just 15 at 23, citing Fay Faraday, Judy Fudge \& Eric Tucker, eds, Constitutional Labour Rights in Canada: Farm Workers and the Fraser Case (Toronto: Irwin Law, 2012).

${ }^{64}$ Vosko, supra note 31 at 235.

${ }^{65}$ Migration for Employment Convention (Revised) No 97, 1 July 1949, 120 UNTS 71, art 6.1 (entered into force 22 January 1952).
} 
substandard housing, which is known to facilitate the transmission of pathogens". ${ }^{66}$ It was acknowledged in the early days of the pandemic that the risk of spreading the COVID-19 virus is much higher in crowded indoor settings. ${ }^{67}$ SAWP workers often share rooms with many other labourers, making preventative social distancing and self-isolation impossible. Given these workers' living conditions, it is hardly surprising that they have been particularly vulnerable to the spread of the virus.

Indeed, according to recent data, between April and October 2020, migrant farm workers in Ontario were ten times more likely to contract COVID-19 than the overall population in Ontario. ${ }^{68}$ By August 2020, over 700 COVID-19 workplace safety claims had been made to Ontario's Workplace Safety and Insurance Board across several farms in Windsor-Essex and Chatham-Kent regions. ${ }^{69}$ Dr. Wajid Ahmed, the medical officer of health for Windsor-Essex, confirmed that most of the virus's spread among farm workers in that region occurred through the workers' congregate living spaces. ${ }^{70}$ The largest of the 30 outbreaks in Ontario's farms in 2020 were found to be on farms where migrant workers lived in bunkhouses. This further strengthened the link between poor housing conditions and outbreaks among the workers. ${ }^{71}$

Even worse, reports have revealed that employers used the government's social distancing policies to their advantage to exploit SAWP workers. Because social distancing while working was not required for those who lived together, some employers had increased the number of labourers living in the same bunkhouse to allow more of them to work together and maximize productivity. ${ }^{72}$ This had the adverse effect of worsening the workers' already inadequate living accommodations while also greatly increasing the risk and severity of outbreaks on the farms.

In fact, after severe outbreaks were reported among Mexican SAWP workers in British Columbia, Mexico's consul general in Vancouver called out the provincial and federal governments for the lack of oversight over the "deplorable" working and living conditions on farms. She highlighted issues such as housing facilities without mattresses covered in trash and infested with cockroaches - observations made based on her visits

${ }^{66}$ YY Brandon Chen, "Chapter D-8: Migrant Health in a Time of Pandemic: Fallacies of Us-VersusThem", in Flood et al, eds, Vulnerable: The Law, Policy and Ethics of COVID-19 (Ottawa: Ottawa University Press, 2020) 407 at 411.

${ }^{67}$ See e.g. Lidia Morawska et al, "How can airborne transmission of COVID-19 indoors be minimised?" (2020) 142:105806 Envtl Intl 1.

${ }^{68}$ See Mark Kelley, Karen Wirsig \& Virginia Smart, "Bitter harvest", CBC News (29 November 2020), online: $<$ https://newsinteractives.cbc.ca/longform/bitter-harvest-migrant-workers-pandemic $>$ [https://perma.cc/H6LA-YL7Z].

69 "More than 700 COVID-19 workplace safety claims made at Windsor-Essex, Chatham-Kent farms", CBC News (14 August 2020), online: <https://www.cbc.ca/news/canada/windsor/wsib-covid-19-windsoressex-farms-1.5685288> [https://perma.cc/SEG8-AAXJ].

70 "Why outbreaks on Windsor-Essex farms continue", CBC News (18 August 2020) at 2m59s, online (video): <https://www.cbc.ca/player/play/1777407555551> [https://perma.cc/BNZ8-3T92].

${ }^{71}$ Ibid at $2 \mathrm{~m} 59 \mathrm{~s}$.

${ }^{72}$ MWAC, supra note 18 at 21. 
to the farms and conversations with thousands of migrant workers over several years. ${ }^{73}$ A grassroots advocate for migrant workers noted that while the government proactively quarantined migrant workers in hotels upon their arrival, the real problem began when they arrived at the farm bunkhouses with 18 workers sharing only three bedrooms ${ }^{74}$ ideal conditions for the rapid spread of COVID-19. There were also reports of farmers locking the bunkhouses shut from the outside, thereby trapping the workers inside. ${ }^{75}$ These examples from British Columbia mirror similar conditions across the country, including in Ontario, where employers have tried to restrict workers' mobility by prohibiting them from leaving the farm and threatening to call law enforcement if they do. ${ }^{76}$

COVID-19 also worsened the challenges SAWP workers faced relative to their employment rights, particularly their exclusion from statutory protections related to maximum hours of work and overtime pay. COVID-19-related concerns and travel restrictions during the spring led to significantly less SAWP workers arriving in Canada in 2020 and many farms operating with fewer workers than expected. As a result, many workers bore the brunt of this shortage, facing heavier workloads and longer hours ${ }^{77}$ without any corresponding compensation. Their increasing pace of work was due to the higher quotas of produce that needed to be collected within a certain time frame by each worker. This resulted in an increased number of injuries. ${ }^{78}$ All of these concerns, including long work hours, intense work pace, and risk of workplace injuries, existed prior to the pandemic, but have since become more acute and widespread.

\section{ii. Case Example: Luis Gabriel Flores Flores}

Workers in all sectors have seen increased threats to their health and safety in the workplace, engaging rights and obligations under the $O H S A .{ }^{79}$ However, unlike other employees, SAWP workers are much less likely to assert their employment-related rights due to concerns of reprisals by employers, who hold a disproportionate amount of control in the employment relationship. A recent decision by the Ontario Labour Relations Board ("OLRB") provides a striking example of retaliation against a migrant farm worker who tried to assert his right to a safe workplace during the pandemic.

\footnotetext{
${ }^{73}$ See Stefan Labbé, “'Conditions are deplorable': Mexican diplomat calls for oversight for B.C. migrant workers”, Tricity News (27 June 2020), online: <https://www.tricitynews.com/news/conditions-aredeplorable-mexican-diplomat-calls-for-oversight-for-b-c-migrant-workers-1.24160957> [https://perma.cc/AC4N-MHZV].

${ }^{74} \mathrm{Ibid}$.

${ }^{75}$ Ibid.

${ }^{76}$ See Kelley, supra note 68.

${ }_{78}^{77}$ See $M W A C$, supra note 18 at 23.

${ }^{78}$ Ibid at 23.

${ }^{79}$ Supra note 19.
} 
In Luis Gabriel Flores Flores $v$ Scotlynn Sweetpac Growers Inc, ${ }^{80}$ Flores, a migrant farm worker from Mexico, was dismissed by his employer after speaking to the media about his health and safety concerns related to his living and working conditions and the COVID-19 virus. Mr. Flores was a worker entitled to protection under section 50(1) of the OHSA. This provision prohibits employers from making reprisals, including in the form of discipline, intimidation, dismissal or threats of dismissal against a worker "because the worker has acted in compliance with this Act" or "has sought the enforcement of this Act". 81

Mr. Flores was employed as a seasonal worker in Canada through the SAWP for several years. In 2020, he was assigned to work at Scotlynn, a farm operation in Norfolk County, southern Ontario. ${ }^{82}$ Mr. Flores' employment contract was for the eight-month period from April to November. Like many other SAWP workers, the bunkhouses in which Mr. Flores and his co-workers lived were in very poor condition and did not allow for social distancing from the other 13 people living there. ${ }^{83}$ Following a COVID-19 outbreak on the farm, Mr. Flores and nearly 200 other workers tested positive for the virus and were required to quarantine for 14 days. ${ }^{84}$ Shortly after the quarantine period ended, one of the workers living in the same bunkhouse as Mr. Flores was hospitalized. The worker later died from COVID-19-related complications. ${ }^{85} \mathrm{Mr}$. Flores confronted his supervisor about how the farm was addressing the worker's health concerns. ${ }^{86}$

The next day, on June 21, 2020, the former owner of the farm confronted Mr. Flores in his bunkhouse, accused him of complaining to the media about the conditions on the farm and told him that he would be sent back to Mexico. ${ }^{87}$ That same day, the employer booked and paid for Mr. Flores to fly back to Mexico that night. ${ }^{88}$ Assuming that he had been dismissed, Mr. Flores spoke to a university professor he had been in contact with about what happened and she arranged for him to be picked up from the farm. ${ }^{89}$ After a few months, in early August, Scotlynn's legal counsel made an offer for Mr. Flores to return to work. Mr. Flores refused due to the poor working conditions and concerns about being exposed to COVID-19. ${ }^{90}$

The OLRB found that Mr. Flores had been dismissed from his employment because of his efforts to seek enforcement of the OHSA, contrary to section 50(1) of the

\footnotetext{
${ }^{80}$ (2020), CanLII 88341 (OLRB) [Flores].

${ }^{81}$ OHSA, supra note $19, \mathrm{~s} 50(1)$.

${ }^{82}$ Flores, supra note 80 at paras 6,8 .

${ }^{83} \mathrm{Ibid}$ at paras 9-10.

${ }^{84} \mathrm{Ibid}$ at paras $11-12$.

${ }^{85} \mathrm{Ibid}$ at para 17.

${ }^{86} \mathrm{Ibid}$ at paras $18-20$.

${ }^{87} \mathrm{Ibid}$ at para 23.

${ }^{88} \mathrm{Ibid}$ at para 28.

${ }^{89} \mathrm{Ibid}$ at paras 30-32.

${ }^{90} \mathrm{Ibid}$ at para 33.
} 
statute. ${ }^{91}$ The finding of dismissal was based on the former owner's confrontation of Mr. Flores in his bunkhouse when he was told he would be sent back to Mexico and the fact that the employer paid for his flight home, which is required when a worker is dismissed, but not if they resign. ${ }^{92}$ The Board awarded Mr. Flores over $\$ 20,000$ in damages, including damages for lost wages, for loss of future earnings, for reasonable expectation of continued employment, and for pain and suffering. ${ }^{93}$ In its reasons, the Board acknowledged the widespread consequences of job loss for SAWP workers like Mr. Flores whose housing and livelihoods are tied to their employers, noting that "Mr. Flores has been forced to find shelter and accommodation as well as live off the charity of others. Although difficult to quantify, he has lost more than simple wages." 94 The Board also explicitly noted Mr. Flores' vulnerability because of his status as a migrant farm worker:

The power imbalance between the employer and Mr. Flores, as a migrant worker who does not speak English and relies on the employer for wages, shelter and transportation, should have been more carefully managed since a reprisal can strike a far deeper wound than might otherwise occur in the traditional employment relationship. Mr. Flores was particularly vulnerable as a temporary worker from Mexico who did not speak the language... ${ }^{95}$

It is rare for a seasonal migrant worker to have their case heard by a labour board. While the OLRB's decision is a win for Mr. Flores, it is more representative of the prevalence of unsafe working conditions and reprisals faced by migrant workers than their ability to seek and obtain meaningful remedies. It is likely that this worker's contact with a professor from Western University and Migrant Workers Alliance for Change ("MWAC") 96 helped him have his case heard, but as Mr. Flores himself stated, "much remains to be done. My coworkers don't have the same opportunities as me."97

\section{iii. Provincial Responses to the Pandemic}

Workers in all sectors have been impacted by the pandemic. However, the pandemic and the provincial government's response have had a differential impact on marginalized groups, such as migrant workers. Despite its recognition of SAWP workers

${ }^{91}$ Ibid at para 42.

${ }^{92} \mathrm{Ibid}$ at paras $71-73$.

${ }^{93}$ Ibid at para 95.

${ }^{94} \mathrm{Ibid}$ at para 88.

${ }^{95} \mathrm{Ibid}$ at para 94.

${ }^{96}$ Ibid at para 12.

${ }^{97}$ Kate Dubinski, "Migrant worker wins labour board case after being fired for speaking out about unsafe conditions amid COVID-19", CBC News (12 November 2020), online:

$<$ https://www.cbc.ca/news/canada/london/migrant-worker-wins-labour-board-ruling-1.5799587>

[https://perma.cc/SVE9-V9BB]. 
as essential and vulnerable, the provincial government has nevertheless refused to adequately compensate and protect them in several key ways.

First, while the closure of many businesses had negative impacts on many lowincome workers, these harmful effects were at least somewhat outweighed for many workers who were able to stay home and protect themselves from the virus and, later, to receive government wage subsidies. However, when Ontario initially passed an emergency regulation requiring the closure of non-essential businesses and activities in March 2020, agriculture and food production were deemed essential services. ${ }^{98}$ As a result, SAWP workers, like other essential workers, were not able to follow public health directives instructing them to "stay home to protect themselves and others from the virus". 99

Second, in late May 2020, the Ontario government announced that it would be providing temporary "pandemic pay" of an additional $\$ 4$ per hour for four months for designated frontline workers. ${ }^{100}$ Workers eligible for this temporary pay boost included those working in health and long-term care, retirement homes, social services, and correctional services. The pandemic pay initiative was described by the government as "a targeted program designed to support employees who work in congregate care settings or primarily with vulnerable persons, where maintaining physical distancing is difficult or not possible" aiming "at helping frontline staff who are experiencing severe challenges and are at heightened risk during the COVID-19 outbreak."101 Although farm work might not be characterized as "frontline", the government had recognized that migrant farm workers themselves are vulnerable persons. However, such recognition did not allow farm workers to be eligible for the pay raise, nor to any other concrete financial help by the government during the pandemic.

The stated goals of the pandemic pay program shed light on why migrant farm workers would naturally be excluded from pandemic pay. These goals include "encourag[ing] staff to continue working and attract[ing] prospective employees" and "help[ing] maintain safe staffing levels and the operation of critical frontline services."102 As discussed above, SAWP workers already risk facing severe consequences for choosing to leave work such as homelessness, loss of legal migration status, and loss of future income opportunities, all of which threaten their health and safety. Further, the

${ }^{98}$ Order Under Subsection 7.0.2 (4) - Closure of Places of Non-Essential Businesses, O Reg 82/20, ss 24-26.

${ }^{99}$ Sarah Berger Richardson, "Worked to the Bone: COVID-19, The Agri-Food Labour Force, and the Need for More Compassionate Post-Pandemic Food Systems", in Flood et al, Vulnerable: The Law, Policy and Ethics of COVID-19 (Ottawa: Ottawa University Press, 2020) at 503.

${ }^{100}$ Government of Ontario, "Eligible workplaces and workers for pandemic pay" (last modified 18 December 2020), online: <https://www.ontario.ca/page/eligible-workplaces-and-workers-pandemic-pay > [https://perma.cc/25EG-ANUV].

${ }^{101}$ Government of Ontario, "COVID-19: Temporary pandemic pay" (last modified 11 December 2020), online: $<$ https://www.ontario.ca/page/covid-19-temporary-pandemic-pay> [https://perma.cc/87H2-JPLQ]. ${ }^{102}$ Ibid. 
incentive to attract more workers is much less effective in the context of seasonal farm work, where international recruitment and employment contracts must align with a relatively fixed seasonal timeline. Finally, "safe staffing levels" for migrant workers on farms has not been shown to be a priority for the government or employers, particularly given that employment legislation and SAWP contracts provide limited protection against excessive work hours to make up for understaffing. Therefore, the use of pandemic pay as a positive incentive to achieve these goals is not necessary for the critically essential service of food production, because the SAWP program is already designed to achieve these objectives by pressuring workers to remain in hazardous conditions under the threat of negative consequences.

Third, although the Ontario government implemented several measures intended to aid migrant workers in dealing with some pandemic-related challenges, these measures had major shortcomings. In mid-June 2020, the province announced that it would commit up to $\$ 15$ million to expanding the Agri-food Workplace Protection Program in order to "enhance health and safety measures on farms and in food processing facilities". ${ }^{103}$ This program was intended to provide cost-share funding for farmers to take additional health and safety measures, such as purchasing personal protective equipment, temporarily housing for ill workers, building physical barriers in the workplace, and enhancing handwashing facilities. ${ }^{104}$ While these measures should have resulted in positive improvements, the funding was only made available to the employers to use as they saw fit. Although it should be in the farmers' interest to prevent outbreaks on their farms, prepandemic living and working conditions suggest that SAWP employers do not always make business decisions with workers' best interests in mind.

\section{iv. COVID-19 Testing and Health Care}

Recognizing the heightened risk of outbreaks among farm workers, the province also facilitated on-site and mobile testing on farms. ${ }^{105}$ However, employers' high degree of control over SAWP workers' hours, transportation, and access to governmentfacilitated testing curtailed government efforts to contain the virus. By July 2020, only 9 out of 176 of the many farm operations in Essex County had participated in the on-site

\footnotetext{
${ }^{103}$ Ontario, Agriculture, Food and Rural Affairs, "Ontario Protecting Agri-Food Workers during COVID19: Government investing \$15 million into health and safety measures for farm operations" (12 June 2020), online: $<$ https://news.ontario.ca/en/release/57189/ontario-protecting-agri-food-workers-duringcovid-19> [https://perma.cc/BN7E-SVLV].

${ }^{104}$ Ibid.

${ }^{105}$ See Government of Ontario, "Ontario Takes Immediate Action to Stop COVID-19 Outbreaks in Windsor-Essex”, supra note 1.
} 
testing provided through Ontario Health. ${ }^{106}$ This is despite Ontario Premier Doug Ford's ardent pleas during press conferences for farmers to allow their employees to get tested. ${ }^{107}$

There were some reports of migrant farm workers in Windsor-Essex County avoiding getting tested out of fear when health officials visited farms. ${ }^{108}$ This fear was well-founded given the many negative repercussions that migrant farm workers are likely to face when they become sick, injured, or otherwise unable to work, including losing their only source of income or being sent back to their home country. According to public health guidelines, for workers outside the farming sector and with full legal status, testing positive for COVID-19 meant that they had to self-isolate for at least 14 days to recover and ensure that they were no longer able to spread the virus when they returned to work. ${ }^{109}$ However, the protocols and protections for SAWP workers who tested positive were far from clear on paper, and even less so in practice. For instance, government wage subsidies such as the Canada Emergency Response Benefit (“CERB”) were generally made available to those who were required to stop working due to a positive COVID-19 test. However, many SAWP workers did not meet the criteria to qualify for CERB. ${ }^{110}$ The province also issued public health guidance allowing asymptomatic COVID-positive farm workers to continue working, as long as they continued following physical distancing and other public health measures to minimize the risk of transmission. ${ }^{11}$ This change was announced in late June, when it was well-established that asymptomatic

\footnotetext{
${ }^{106}$ See "Few Windsor-Essex farms conducting on-site COVID-19 testing through Ontario Health", $C B C$ News (21 July 2020), online: <https://www.cbc.ca/news/canada/windsor/few-essex-county-farms-on-sitetesting-1.5658054> [https://perma.cc/2UKQ-J7K5].

${ }^{107}$ See e.g. "Work with us:' Ford expresses frustration farmers not bringing migrant workers to be tested", City News (17 June 2020) at 00h00m45s, online (video):

$<$ https://toronto.citynews.ca/video/2020/06/17/work-with-us-ford-expresses-frustration-farmers-notbringing-migrant-workers-to-be-tested/> [https://perma.cc/9CLW-TR78]; see also The Canadian Press, "Protect migrant workers or face consequences, Ford and Trudeau warn farmers", CTV News (22 June 2020), online: $<$ https://toronto.ctvnews.ca/protect-migrant-workers-or-face-consequences-ford-andtrudeau-warn-farmers-1.4995281> [https://perma.cc/UY6Q-HY3L]; "Ford once again urges farmers to get migrant workers tested for coronavirus", City News (23 June 2020) at 00h00m21s, online (video): $<$ https://toronto.citynews.ca/video/2020/06/23/ford-once-again-urges-farmers-to-get-migrant-workerstested-for-coronavirus/> [https://perma.cc/3X2P-B4UY].

${ }^{108}$ See e.g. Shawn Jeffords, "Migrant farm workers 'hid' from COVID-19 testing in Windsor-Essex: Ford", Toronto Star (2 July 2020), online: <https://www.thestar.com/news/canada/2020/07/02/migrantfarm-workers-hid-from-covid-19-testing-in-windsor-essex-ford.html $>$ [https://perma.cc/8RT3-9KX8]. ${ }^{109}$ Government of Ontario, "COVID-19: self-isolation and return to work" (last modified 16 December 2020), online: <https://www.ontario.ca/page/covid-19-self-isolation-and-return-work> [https://perma.cc/MYQ8-52CU].

${ }^{110}$ Government of Canada, "Canada Emergency Response Benefit (CERB)" (last modified 30 April 2021), online: $<$ https://www.canada.ca/en/services/benefits/ei/cerb-application.html> [https://perma.cc/9H6X-PN79].

${ }^{111}$ See Government of Ontario, "Ontario Takes Immediate Action to Stop COVID-19 Outbreaks in Windsor-Essex", supra note 1.
} 
carriers could still spread the virus to others ${ }^{112}$ and was completely at odds with the public health guidance for other Ontarians. This policy effectively negated much of the value of testing, since it effectively required many workers who tested positive to continue working instead of self-isolating.

In addition, the province enacted new legislation to create an unpaid, jobprotected Infectious Disease Emergency Leave for employees unable to work for designated reasons related to COVID-19, including those who are in isolation or quarantine in accordance with public health directives. ${ }^{113}$ However, such unpaid leave, even if duly provided by the employer, does not practically meet the needs of SAWP workers, as they have a limited period of time to earn income on which they depend for their livelihoods.

In addition to the shortcomings inherent in these government measures, SAWP workers who tested positive, regardless of whether they ended up isolating or not, remained at the mercy of their employers for being called back to work on the farm in subsequent years. This structural disincentive undermined the health of SAWP workers while also highlighting the precariousness of their employment. In sum, COVID-19 has exacerbated the significant existing barriers to the exercise of employment and labour rights for migrant farm workers, while simultaneously heightening their risk of contracting the virus, thereby creating a vicious cycle of structural vulnerability.

\section{IMMIGRATION LAW DIMENSION OF MIGRANT FARM WORKER VULNERABILITY}

\section{a) Globalization and Colonial Legacies}

One important factor exacerbating the precariousness of SAWP workers is globalization and its colonial legacies. While many challenges faced by SAWP workers are attributable to the current employment and labour regime, these challenges are also deeply rooted in Canada's migration regime, which is situated within a "global system of racialized capitalism." 114 This system has "create[d] a pool of expropriated and racialized workers from the periphery keen to find employment in Canada and other 'core' countries of the global north, even on terms and conditions that exploited workers in those countries are loathe to accept." 115 This explains why SAWP and other agricultural workers are

\footnotetext{
${ }^{112}$ See e.g. Dr Angela N Baldwin \& Sony Salzman, "What we know and don't about asymptomatic transmission and coronavirus", ABC News (1 April 2020), online:

$<$ https://abcnews.go.com/Health/asymptomatic-transmission-coronavirus/story?id=69901758>

[https://perma.cc/HC59-YCSY].

${ }^{113}$ Employment Standards Amendment Act (Infectious Disease Emergencies), 2020, SO 2020, c 3, amending Employment Standards Act, RSO 2000, c 41, s 4.

114 Vosko, supra note 31 at 234.

115 Ibid.
} 
mainly persons of colour with low education levels recruited exclusively from Mexico and Caribbean countries - countries with legacies of colonization and forced labour, including slavery.

This phenomenon of reliance on workers from Latin America and the Caribbean in the Canadian agricultural sector is the by-product of colonial legacies as well as modern globalization. ${ }^{116}$ Globalization can exert negative pressure on labour standards in developing countries, where lower labour costs and a relatively abundant supply of socalled "unskilled" workers can become a comparative advantage in international trade. ${ }^{117}$ Racism has allowed the rigid and differential treatment of workers from many formerly colonized countries to persist. ${ }^{118}$ Thus, "it is not coincidental that Canada recruits a racialized workforce from the global south to participate in its migratory work programs, while severely limiting if not eliminating their ability to obtain permanent residence."119 In this way, the challenges faced by migrant farm workers cannot be fully understood solely from an employment and labour relations perspective. The federal government has actively designed the SAWP program (and its TFW and immigration schemes more generally) to create differential, racialized, and unfree labour conditions for migrant workers that do not apply to domestic workers. ${ }^{120}$

\section{i. Immigration Legislation}

As foreign nationals, SAWP workers must meet the criteria established under the Immigration and Refugee Protection Act ("IRPA") ${ }^{121}$ and its regulations to enter and remain in Canada. In many respects, the requirements to do so are the same as in other streams under the TFWP. Foreign nationals must apply for and obtain a visa ${ }^{122}$ and demonstrate that they have a genuine offer of employment which will likely have a neutral or positive economic effect on the labour market in Canada." 123 When these conditions are met, a work permit is granted. However, this is generally a closed work permit

${ }^{116}$ UWI TV, "Canada-Caribbean Institute Forum on Seasonal Farm Workers in Canada during the COVID19 Pandemic Pt 1 " (2 June 2020) at 00h:29m:45s, online (video): <https://uwitv.org/pfrm/canadacaribbean-institute-forum-on-seasonal-farm-workers-in-canada-during-the-covid19-pandemic-pt-1> [https://perma.cc/LX3V-5SYG].

${ }^{117}$ See e.g. Kevin Banks, "Globalization and Labour Standards--A Second Look at the Evidence" (2004) 29 Queen's LJ 533 at 537-39.

${ }^{118}$ See Frédéric Mégret, "Transnational Mobility, the International Law of Aliens, and the Origins of Global Migration Law" (2017) 111 AJIL Unbound 13 at 16.

${ }^{119}$ Vosko, supra note 31 at 234; see also Smith, supra note 63 at 34.

${ }^{120}$ See e.g. Vic Satzewich, Racism, and the Incorporation of Foreign Labour: Farm Labour Migration to Canada since 1945 (London: Routledge, 1991) at 10, cited in Smith, supra note 63 at 28-29.

${ }^{121}$ SC 2001, c 27 [IRPA].

$122 \mathrm{Ibid}, \mathrm{s} 11(1)$.

${ }^{123}$ Immigration and Refugee Protection Regulations, SOR/2002-227, ss 200(1)(c)(iii), 203(1)(b) [IRPA Regulations]. 
restricting TFWs to work for the designated employer for a specified length of time, ${ }^{124}$ which operates to "immobilize" migrant workers and undermine any potential local gains related to employment and labour rights. ${ }^{125}$ It is the immobilizing effect of this closed work permit structure that renders migrant workers much more vulnerable to exploitation than Canadian workers.

SAWP workers are even more marginalized because, unlike many other TFWs, they are problematically excluded from the categories of persons eligible to apply for permanent residence. ${ }^{126}$ They are not eligible to apply under the "economic class", which aims to attract educated persons with financial stability and official language proficiency ${ }^{127}$ - attributes which the SAWP largely precludes by design. In contrast, the government has maintained a perpetually vulnerable and unfree labour supply through the SAWP. This has effectively created a subclass of workers ${ }^{128}$ who will never access full, equal status in Canada and who are perpetually deemed "temporary" despite participating in the program for decades. Further, this boundary of "permanent temporariness" is drawn along distinctly racialized lines, ${ }^{129}$ leading to a separation of workers from the Caribbean and Mexico from other classes of migrants, more often from developed countries (such as the United States and European countries), who are deemed worthy of the opportunity to apply for permanent status in Canada.

\section{ii. Role of Foreign Governments}

The governments of sending states also play a role in creating structural vulnerabilities for SAWP workers who arrive to work in Canada. These governments are responsible for recruiting candidates for the SAWP program and organizing pre-departure activities for workers. ${ }^{130}$ They design parts of their recruitment processes to support what some scholars identify as one of the Canadian government's policy objectives: preventing SAWP workers from settling as permanent residents in Canada. ${ }^{131}$ As such, foreign governments recruit workers who are more likely to return to their home country after their employment contract ends. For example, the Mexican government has reportedly favoured recruiting married candidates with children because they would be more likely

\footnotetext{
${ }^{124}$ See Irma Fabiola Cruz-Lopez, The Seasonal Agricultural Workers Program: Looking at Mexican Participation Through a Magnifying Glass, (PhD Thesis, University of Ottawa Faculty of Law, 2013) [unpublished] at 95.

${ }^{125}$ Smith, supra note 63 at 31-32.

${ }^{126}$ See IRPA, supra note 121, s 12; IRPA Regulations, supra note 123, ss 64-65 and 70(2).

${ }^{127}$ See Cruz-Lopez, supra note 124 at 97.

${ }^{128}$ See Marsden, supra note 35 at 41.

${ }^{129}$ Patti Tamara Lenard \& Christine Straehle, eds, Legislated Inequality: Temporary Labour Migration in Canada (Kingston and Montreal: McGill Queens Press, 2012) at 121; see also Marsden, supra note 35 at 58.

${ }^{130}$ Lenard, supra note 129 at 52.

${ }^{131} \mathrm{Ibid}$ at $53-54$.
} 
to return to their families in Mexico compared to single workers with no children. ${ }^{132}$ Similarly, another common sending state policy involves preventing couples from migrating for work together. The resulting separation of workers from their families creates another significant vulnerability for SAWP workers. ${ }^{133}$ Such policies contribute to the purported "success" of the SAWP in terms of its circularity or high rate of return of workers' return to their home countries, ${ }^{134}$ to the detriment of the workers' well-being.

\section{iii. Local Racialization}

Finally, SAWP workers face challenges related to their status as migrants in the form of the racialization and outright racism which they experience in the communities surrounding the farms where they work. ${ }^{135}$ The racial exclusion and alienation of migrant workers from local communities is present in media discourse, which draws on prejudicial stereotypes to portray foreign workers as violent threats to local communities. ${ }^{136}$ This exclusionary discourse has become even more contradictory since the onset of the COVID-19 pandemic because the media, governments, and employers refer to temporary farm workers as "essential" without countering the narrative that the workers are to blame for the spread of the virus in local communities.

\section{b) Private Contractualization of Immigration Law}

Another factor exacerbating the precariousness of SAWP workers is their "deportability". ${ }^{137}$ Clause X(2) of the Mexican SAWP employment contract and Clause XII(1) of the Caribbean SAWP contract entitles the employer to "prematurely cease" the worker's employment "for non-compliance, refusal to work, or any other sufficient reason", and to effectively repatriate the worker to their country of origin. ${ }^{138}$ This condition arises out of the contractual employment agreement, despite the questionable validity of these termination clauses in Ontario. ${ }^{139}$ Critically, it is this threat of

\footnotetext{
132 Ibid.

${ }^{133}$ Ibid. Notably, immigration policies that encourage family separation are contrary to the stated objective of family reunification under s 3(1)(d) of the IRPA.

${ }^{134}$ Ibid. See also Karl Flecker, "Canada's Temporary Foreign Worker Program (TFWP): Model Program - or Mistake?” Canadian Labour Congress (April 2011), online (pdf): <http://ccrweb.ca/files/clc_modelprogram-or-mistake-2011.pdf $>$ [https://perma.cc/6CKR-QTTB] at 2.

135 See Vosko, supra note 31 at 236.

${ }^{136}$ See Harald Bauder, "Foreign farm workers in Ontario (Canada): Exclusionary discourse in the newsprint media" (2008) 35:1 J Peasant Stud 100 at 101.

${ }^{137}$ Cruz-Lopez, supra note 124 at 104.

138 SAWP Contract - Caribbean, supra note 12, s XII(1); SAWP Contract-Mexico, supra note 16, s $\mathrm{X}(2)$. Note that the contract for Mexican workers includes the wording "any other sufficient reason stated in this contract" [emphasis added], which is absent from the contract for Caribbean workers.

${ }^{139}$ Ontario courts have applied fairly rigid approaches to determining the enforceability of termination clauses in employment contracts: see e.g. Waksdale v Swegon North America Inc, 2020 ONCA 391;
} 
deportation, in addition to the risk of job loss, that heightens the precarity of SAWP workers. As a result of this threat, SAWP workers are unlikely to be able to assert any of their employment-related rights. Instead, they are likely be repatriated to their home country before an Employment Standards Officer or the Ontario Labour Relations Board is able to make any determinations regarding reprisals, wrongful dismissal, or other rights violations. ${ }^{140}$ Even worse, being dismissed in this way is likely to result in a negative employer evaluation, which in turn would typically exclude the worker from participating in the SAWP in the future. ${ }^{141}$ This practice of "blacklisting" further entrenches workers" structural vulnerability ${ }^{142}$ by discouraging them from asserting their rights for fear of losing future income opportunities.

Further, these repatriation provisions do not allow SAWP workers a right of appeal, despite their original authorization to remain in Canada for the duration of their work permit. ${ }^{143}$ The clauses thus contractualize and privatize immigration decisions which in other circumstances would remain within the exclusive jurisdiction of the federal government to make. The clauses refer to "consultation" with a government agent in the event of dismissal and removal. However, in practice, the decision to repatriate a SAWP worker still largely rests with a private employer, raising serious concerns about a lack of procedural fairness safeguards and standards of judicial review which are normally accorded to administrative decision-making. ${ }^{144}$ This phenomenon is likely accepted by the government because of the "exceptionalism" that justifies and legitimizes suspending normal rights for migrant workers. ${ }^{145}$

Furthermore, since SAWP workers are technically not employed during the period when the standard-form employment agreements are reviewed by the federal government, they are effectively excluded from negotiating the terms of these contracts. ${ }^{146}$ In this way, the federal government in its administrative capacity reinforces provincial-level barriers to the full exercise of employment and labour rights by migrant farm through traditional negotiation mechanisms.

As discussed above, many SAWP workers (and other TFWs) are reluctant to exercise any formal rights they may have under employment and human rights legislation due to the fear of employer reprisals and the fear of deportation. ${ }^{147}$ The private

Rutledge v Canaan Construction Inc, 2020 ONSC 4246; Khashaba v Procom Consultants Group Ltd, 2018 ONSC 7617; Wood v Fred Deeley Imports Ltd, 2017 ONCA 158.

${ }^{140}$ See Cruz-Lopez, supra note 124 at 141-42; see also Hastie, supra note 32 at 34-35.

${ }^{141}$ See Cruz-Lopez, supra note 124 at 141.

${ }^{142}$ See UWI TV, supra note 116 at $0 \mathrm{~h}: 32 \mathrm{~m}: 30 \mathrm{~s}$.

${ }^{143}$ Lenard, supra note 129 at 55.

${ }^{144}$ See e.g. Baker v Canada (Minister of Citizenship and Immigration), [1999] 2 SCR 817, 174 DLR (4th) 193; see also Canada (Minister of Citizenship and Immigration) v Vavilov, 2019 SCC 65.

${ }^{145}$ Lenard, supra note 129 at 120.

${ }^{146}$ See Cruz-Lopez, supra note 124 at 56-57.

${ }^{147}$ Ibid at 55; see also Vosko, supra note 31 at 230; Hastie, supra note 32 at 34-35; Chen, supra note 66 at 411 . 
contractualization of immigration decisions through the threat of deportation and blacklisting thus creates and deepens structural vulnerabilities for SAWP workers.

\section{c) Effect of COVID-19}

The pandemic has, unsurprisingly, exacerbated the effects of racialized migration policies on SAWP workers, including through the initial travel ban on migrant workers, the quarantine and self-isolation rules, and access to health care and income support.

\section{i. Initial Travel Restrictions}

In late March 2020, the federal government imposed heavy travel restrictions under the Quarantine Act, ${ }^{148}$ including an Order in Council prohibiting most foreign nationals from entering Canada if they arrived from a country other than the United States. ${ }^{149}$ Temporary migrant workers, including those participating in the SAWP, were initially not included among the exempt categories of individuals still allowed to enter Canada. This caused significant outcry from Ontario's agricultural sector, as farm employers had time-sensitive demands for the SAWP labour that they were used to relying on annually. Agricultural employer groups stated that they were "working vehemently with [their] partners to ensure growers will have the labour resources they require". They called on the federal government to find a way for workers to safely be brought to Canada - a call echoed by a Member of Parliament representing an agricultural region in southern Ontario. ${ }^{150}$ Responding to these concerns, the federal government

quickly conceded and granted travel exemptions for migrant farm workers. ${ }^{151}$ It was not purely local politics and employers' interests at stake. Rather, it has long been acknowledged that SAWP workers are critically essential to Canada's local food supply, and serious food shortages would be a likely consequence of barring all migrant farm workers from coming to Canada in time for seasonal planting and harvesting.

Prohibiting SAWP workers from entering Canada would also have had a harmful impact on the workers themselves, who rely heavily on the income from seasonal work

\footnotetext{
148 SC 2005, c 20, s 58.

${ }^{149}$ Minimizing the Risk of Exposure to COVID-19 in Canada Order (Prohibition of Entry into Canada from any country other than the United States), PC 2020-162 (2020) C Gaz I 154.

${ }^{150}$ Andrew Lupton, "COVID-19 restrictions on migrant workers will be devastating, Ontario farmers warn” CBC News (17 March 2020), online: <https:/www.cbc.ca/news/canada/london/covid-19restrictions-on-migrant-workers-will-be-devastating-ontario-farmers-warn-1.5500269>

[https://perma.cc/ETZ6-GDGV]; see also Sanjay Maru, “Conservative MP calling on federal government to permit migrant workers into Canada” CBC News (18 March 2020), online:

$<$ https://www.cbc.ca/news/canada/windsor/dave-epp-calling-for-liberals-to-allow-seasonal-workers1.5500816> [https://perma.cc/GQB2-UDKT].

${ }^{151}$ See Kate Dubinski, "Canada lifts restrictions on foreign workers, including migrant farm labourers" CBC News (21 March 2020), online: <https:/www.cbc.ca/news/canada/london/canada-lifts-travelrestrictions-for-foreign-workers-1.5505579> [https://perma.cc/CB2P-NW3G].
} 
in Canada. Initial border closures resulted in delays in travel arrangements from SAWP workers' home countries, often leaving them stranded in major cities to which they had travelled from their rural communities in order to catch their flights. ${ }^{152}$ These workers often had no disposable income to afford return transportation to their hometown or to pay for accommodation in the cities in which they were stuck. ${ }^{153}$ For workers who would eventually arrive in Canada, the delays would affect the length of their work term and therefore the amount of income they could earn during the limited SAWP employment period.

\section{ii. Quarantine and Self-Isolation}

The conditions underlying the outbreaks among migrant farm workers is yet another example of the racialization of pandemic risk. In addition to border restrictions, there were severe shortcomings in the federal government's introduction of quarantine guidelines for farms employing migrant workers. On March 24, 2020, the federal government made an Order in Council imposing a mandatory, 14-day self-isolation period for individuals entering Canada. ${ }^{154}$ However, nearly a month passed before amendments to the Immigration and Refugee Protection Regulations ("Regulations") came into effect to address employers' specific responsibilities related to the self-isolation and quarantine requirements of foreign workers. ${ }^{155}$ This timing gap between introduction of the different government directives likely led to much confusion and uncertainty regarding employers' responsibilities in preventing the spread of the virus among SAWP workers. Section 209.2(1)(a) of the Regulations was updated to require an employer to pay migrant workers in quarantine "wages during that period that are substantially the same as those set out in the offer of employment"156 and to provide migrant workers who developed symptoms of COVID-19 "with accommodations that have a bedroom and bathroom that are solely for the use of the foreign national while they isolate themselves." "157 The Regulations also provided that employers "must not do anything that prevents the foreign national from complying with the requirements of" government orders or regulations under the Emergencies Act or the Quarantine Act, or provincial laws governing COVID-19 health responses, "including requiring the foreign national to do anything that is contrary to [those laws or requirements]". ${ }^{158}$

\footnotetext{
152 See $M W A C$, supra note 18 at 16.

153 Ibid at 16.

${ }^{154}$ Minimizing the Risk of Exposure to COVID-19 in Canada Order (Mandatory Isolation), PC 2020-175

(2020) C Gaz 1 154, ss 2, 5.

${ }^{155}$ Regulations Amending the Immigration and Refugee Protection Regulations (Emergencies Act and Quarantine Act), SOR/2020-91.

${ }_{156}$ Ibid, s 209.2(1)(a)(vii).

${ }^{157} \mathrm{Ibid}$, s 209.3(1)(a)(xi).

${ }^{158} \mathrm{Ibid}$, ss 209.2(1)(a)(v)-(vi), 209.3(1)(a)(vii)-(viii).
} 
In practice, many of the quarantine guidelines and requirements were not respected. Many workers from different regions were cramped into the same living space during their required quarantine period. Others were required to begin working as soon as they arrived without having gone through the isolation period and were unable to physically distance while performing their job duties. ${ }^{159} \mathrm{MWAC}$ received reports from 365 workers at several greenhouses that their housing conditions did not allow them to physically distance, including during the quarantine period. ${ }^{160}$ This failure of employers to ensure respect for quarantine protocols was a manifestation of the pre-pandemic problem of poor housing conditions for migrant farm workers, as discussed earlier in this paper. While the amended Regulations granted Service Canada the authority to conduct inspections of employer compliance with COVID-19 related requirements with and without notice, ${ }^{161}$ inspections were mainly being conducted virtually and not proactively, ${ }^{162}$ making them less effective at detecting non-compliance on the ground. Further, although Employment and Social Development Canada set up a tip line through which workers could make complaints about employer non-compliance, workers were not informed about this on or prior to their arrival, and the tip line was inaccessible to many migrant workers who did not speak English or French and who did not have local Canadian phone numbers. ${ }^{163}$

The quarantine guidelines were "designed with the protection of non-migrant populations in mind" rather than "to ensure that migrant workers are themselves protected from risk of infection" in ways such as preparing workplaces to be safe for workers upon their arrival. ${ }^{164}$ Instead, the two-week isolation period for workers upon arrival was based on the assumption that the arriving workers are the vectors of the disease rather than being themselves vulnerable to contracting it from locals or other migrant workers on the farm. ${ }^{165}$ This is despite research confirming that migrant workers are usually healthier than locals upon their entry into Canada, but face worse health outcomes due to their often hazardous and unsanitary living and working conditions. ${ }^{166}$ As one scholar explains:

\footnotetext{
159 See $M W A C$, supra note 18 at 19.

${ }^{160}$ Ibid at 17.

${ }^{161}$ See Employment and Social Development Canada, "Compliance inspections for Employers of the Temporary Foreign Worker Program during a pandemic" (24 April 2020), online:

$<$ https://www.canada.ca/en/employment-social-development/services/foreign-workers/employercompliance/covid-inspections.html> [https://perma.cc/B4BZ-TJ9P].

162 See $M W A C$, supra note 18 at 18.

163 Ibid.

164 Ibid.

165 See UWI TV, supra note 116 at $00 \mathrm{~h}: 40 \mathrm{~m}: 41 \mathrm{~s}$.

${ }^{166}$ Ibid at 0h:34m:40s; see also Zoua M Vang et al, "Are immigrants healthier than native-born Canadians? A systemic review of the healthy immigrant effect in Canada" (2017) 22:3 Ethn \& Health 209.
} 
...upon arrival in Canada, international migrants on average exhibit equal if not better health than their native-born counterparts. But this relative health advantage dissipates over time, in part due to migrants' encounter with discrimination in receiving communities. Notwithstanding this reality, public policy and discourse in Canada regularly conjure up images of migrants as diseased and dangerous rather than as a population vulnerable to the adverse effects of ill health. Canada's responses to the COVID-19 pandemic to date have proven to be no different. ${ }^{167}$

In this way, shortcomings in the requirements and guidelines both for the initial quarantine period and for preventing pandemic health risks afterwards have contributed to SAWP workers' immensely disproportionate exposure to the virus. As mentioned earlier in this paper, migrant farm workers were ten times more likely to contract COVID19 compared to Ontarians overall. ${ }^{168}$ Tragically, by mid-June, several hundred SAWP workers had become infected, and at least three Mexican workers died from COVID-19 following the many outbreaks on Ontario farms, specifically in the Windsor-Essex and Norfolk County regions. ${ }^{169}$ The deaths of the first two Mexican workers prompted the Government of Mexico to briefly pause sending migrant workers to Canada until the two governments reached an agreement on improving health and safety protections for Mexican agricultural labourers. ${ }^{170}$

The disproportionate impact of COVID-19 on migrant farm workers (and migrants in general) is unsurprising since it has been widely documented that racialized communities, including Black communities, are at a higher risk of contracting COVID19, including for reasons related to income-level and their housing and working environments. ${ }^{171}$ The outbreaks on Ontario farms are in many ways comparable to outbreaks at meat processing facilities, such as the Cargill meat plant in Alberta. At Cargill, a high proportion of vulnerable workers who were immigrants or had a precarious migration status contracted the virus while working under conditions that did not respect government health protocols. ${ }^{172}$

\footnotetext{
${ }^{167}$ Chen, supra note 66 at 408.

${ }^{168}$ See Kelley, Wirsig \& Virginia Smart, supra note 68.

${ }^{169}$ Sofia Rodriguez, "Third Ontario migrant worker dies of COVID-19" CBC News (21 June 2020), online: $<$ https://www.cbc.ca/news/canada/london/third-ontario-migrant-worker-dies-of-covid-191.5621487> [https://perma.cc/UJS4-3Q6B].

170 "Mexico to resume sending farm workers to Canada after COVID-19 safety agreement" CBC News (21 June 2020), online: $<$ https://www.cbc.ca/news/world/mexico-farm-workers-canada-resumecoronavirus-1.5621668> [https://perma.cc/4E54-XHNR].

${ }^{171}$ See e.g. Emily Chung et al, "Black Canadians get sick more from COVID-19. Scientists aim to find out why" CBC News (25 September 2020), online: $<$ https://www.cbc.ca/news/health/black-covidantibody-study-1.5737452> [https://perma.cc/Y5M8-JM2D]; Ladan Golestaneh et al, "The association of race and COVID-19 mortality" (2020) 25 EClinicalMedicine,

${ }^{172}$ See Richardson, supra note 99 at 504-505; see also Chen, supra note 66 at 410.
} 


\section{iii. Access to Health Care and Income Support}

The disproportionate impact of COVID-19 on migrant farm workers is also linked to unequal access to health care services. Pre-pandemic, it was standard practice for migrants' health care to depend on their migration and residency status in Canada, with entitlements varying between provinces. ${ }^{173}$ In this regard, Ontario has responded to pandemic health concerns more generously than many other Canadian jurisdictions by temporarily expanding essential health care coverage to previously uninsured people in the province such as SAWP workers. ${ }^{174}$

However, as with employment standards and quarantine procedures, rights, and polices on paper do not always materialize on the ground. Ontario's expanded coverage has not been implemented consistently, resulting in many migrants being required to pay for health services that were supposed to be covered. ${ }^{175}$ Moreover, even though SAWP workers are eligible for the Ontario Health Insurance Plan after three months, access to the provincial health insurance plan is mediated through employers, who are responsible for arranging the coverage. ${ }^{176}$ In practice, many SAWP workers faced significant delays in their health cards. ${ }^{177}$

In addition, SAWP workers were very unlikely to qualify for income support should they be unable to work for reasons related to COVID-19. The lack of access to Employment Insurance benefits or benefits like CERB gave SAWP workers no other option but to continue working even if they felt they were at risk of contracting or spreading the virus. Furthermore, workers' precarious migration status and "deportability" likely deterred them from accessing health care. ${ }^{178}$ These factors both increased the risks of community transmission. ${ }^{179}$ The differential treatment of migrant farm workers is thus not only discriminatory and dangerous for the workers themselves, but it also harms other non-migrants in the wider community. In this sense, "from a policy standpoint, leaving migrants out of government health care and income support programs during the pandemic also puts public health at risk." 180

\footnotetext{
${ }^{173}$ See Chen, supra note 66 at 412.

${ }^{174} \mathrm{Ibid}$; see also Ontario Ministry of Health, "COVID-19 Expanding Access to OHIP Coverage and Funding Physician and Hospital Services for Uninsured Patients" (25 March 2020), online: $<$ health.gov.on.ca/en/pro/programs/ohip/bulletins/4000/bul4749.aspx $>$ [https://perma.cc/K3CQ-URCQ]. ${ }^{175}$ See e.g. Emma Paling, "Migrants in Ontario Aren't Getting the Free Health Care They were Promised" Huffington Post (22 April 2020), online: <huffingtonpost.ca/entry/migrants-ontariocoronavirus-free-health-care_ca_5ea062eec5b69150246c07f7> [https://perma.cc/CG3W-LXR3]. ${ }^{176}$ See Employment and Social Development Canada, "Hire a temporary worker through the Seasonal Agricultural Worker Program: Program requirements" (7 December 2020), online: $<$ https://www.canada.ca/en/employment-social-development/services/foreignworkers/agricultural/seasonal-agricultural/requirements.html $>$ [https://perma.cc/CP5U-T9VH]. ${ }^{177}$ See $M W A C$, supra note 18 at 13.

${ }^{178}$ See Chen, supra note 66 at 415.

179 Ibid at 417.

${ }^{180}$ Ibid.
} 


\section{URGENCY AND OPPORTUNITY FOR STRUCTURAL CHANGE}

The severe and disproportionate impact of COVID-19 on SAWP workers has exposed many long-term, structural problems and rendered the need to find solutions to these problems much more urgent. This increased immediacy is a result of both the serious, short-term health and safety threats at the individual and public health levels and Canada's dependency on SAWP workers for its food supply. Despite isolated government measures to address some of the problems exacerbated by COVID-19, provincial and federal governments have failed to address the underlying conditions causing SAWP workers' vulnerability to the virus. Structural changes must instead be effected to give SAWP workers equal rights with respect to employment and migration, as well as an equal opportunity to actually exercise those rights. Such changes could include measures such as open-work permits, the removal of repatriation clauses from the SAWP employment agreements, stronger collective bargaining rights, and pathways to more permanent migration in Canada. Both local advocates and government officials have recognized that the pandemic had brought a moment of "reckoning in which many of the historical problems surrounding migrant agricultural workers have become at once worse and public". ${ }^{181}$ The harmful, permanently temporary status of seasonal farm workers used to justify their severely limited rights has never been sustainable. The year 2020 was a wake-up call, exposing just how urgently these structures need to change.

Along with this unprecedented urgency, there is also unprecedented opportunity to achieve the necessary structural changes in the realms of labour and immigration law and policy. COVID-19 had incited a global reflection on how governments and the public both in Canada and around the world organize and understand aspects of our societies that were previously taken for granted, including labour, health care, mobility, social security, and community. It forced governments to determine which goods, services, activities, and jobs are "essential" and which are not, and to carefully balance core human rights, personal liberties, and economic considerations with important public health concerns. The word "vulnerable" had become prominent in discourse about community members who are most at-risk of contracting the virus. In rethinking many of these spheres of everyday life, it becomes necessary to question many things that underpin the structures of the SAWP, including food supply, employment relationships, international migration, and the interconnection between individual and public health. Meanwhile, the tragic COVID-19 outbreaks and deaths among SAWP workers in Ontario have taken up

prominent space in mainstream media, forcing many Canadians to reconcile their "new normal" with the exclusionary and unfair treatment of now-deemed essential migrant farm workers.

${ }^{181}$ Labbé, supra note 73. 
A key feature of discourse about migrant farm workers since the COVID-19 outbreak has been the shift in their characterization from "low-skilled" to "essential" workers in the Canadian economy. ${ }^{182}$ This reflects the reality that agricultural work, apart from being extremely difficult and physically demanding, does, in fact, require skill and training in order for workers to be productive. ${ }^{183}$ Thus, when Canada's travel ban initially applied to migrant farm workers, employers and stakeholders in the industry did not hesitate to admit that unemployed Canadians could not simply replace this migrant labour on which they have relied for decades. ${ }^{184}$ When the federal government updated its travel exemptions to include temporary foreign workers, its press release explicitly stated that "[a]llowing foreign workers to enter Canada recognizes their vital importance to the Canadian economy, including food security for Canadians". ${ }^{185}$

One scholar commented that "[w]e are experiencing a unique moment in history, as consumers are forced to ask questions about where our food comes from, and to think about the people who harvest, process, transport, shelve, and deliver the food we eat. Our ability to put food on our plates is inextricably bound up in their well-being." "186 Similarly, a paper published by the International Organization for Migration notes that " $\mathrm{t}] \mathrm{he}$ pandemic has inverted previous hierarchies of more and less desired (and disposable or not) migrant workers and brought to the fore questions about the impacts of border closures on people and the economy during the crisis and into the future." "187 Some of the minor legislative changes made by the Canadian government show potential political openness to improving conditions for migrant workers, and the Flores case represents an important recognition for injustices migrant workers face, and an incremental move towards allowing migrant workers to exercise their rights through the judicial system. In this way, the pandemic has wedged an opening in the consciousness of Canadian policymakers and the public as to the importance of protecting marginalized essential workers like those in the SAWP and the need for more sustainable, equitable, and safe labour, migration and health policies. While much work remains to be done such as addressing racial prejudices still prevalent in Canada, this opening may create space for meaningful policy change to address structural barriers for migrant farm workers.

\footnotetext{
${ }^{182}$ See UWI TV, supra note 116 at $00 \mathrm{~h}: 38 \mathrm{~m}: 19 \mathrm{~s}$.

${ }^{183}$ Ibid at 00h:39m:20s.

${ }^{184} \mathrm{Ibid}$ at 00h:38m:40s; see also Lupton, supra note 150.

${ }^{185}$ Immigration, Refugees and Citizenship Canada, "Canada provides update on exemptions to travel restrictions to protect Canadians and support the economy" (last modified 27 March 2020), online: $<$ https://www.canada.ca/en/immigration-refugees-citizenship/news/2020/03/canada-provides-update-onexemptions-to-travel-restrictions-to-protect-canadians-and-support-the-economy.html> [https://perma.cc/M3GJ-8Q3L].

${ }^{186}$ Richardson, supra note 99 at 508-509.

${ }^{187}$ Anna Triandafyllidou \& Lucia Nalbandian, “'Disposable' and 'essential': Changes in the global hierarchies of migrant workers after COVID-19” (August 2020), online (pdf): International Organization for Migration <https://publications.iom.int/system/files/pdf/disposable-and-essential.pdf> [https://perma.cc/5VXF-VKKL] at 1 .
} 


\section{CONCLUSION}

The COVID-19 pandemic has caused increased public awareness of a wide array of longstanding barriers faced by SAWP workers in Ontario, particularly in the areas of immigration law and employment and labour law. While COVID-19 has created new health challenges for migrant farm workers, it has also exacerbated existing structural problems that contribute to workers' vulnerability and which cannot be dismissed as merely the inevitable consequences of the pandemic.

Many systemic changes are needed to redress these structural problems, namely: ending unfair employment standards exemptions for agricultural workers, granting agricultural workers equal and meaningful statutory protections of their right to collective bargaining, ending bonded labour practices by granting workers open work permits, establishing meaningful minimum standards for housing and working conditions, empowering workers to access healthcare and other services without relying directly on their employers, and creating pathways for SAWP workers to obtain permanent residency in Canada. While incremental changes to existing labour and immigration policies may help improve some of the SAWP workers' working conditions, only these deeper, structural changes will meaningfully reduce their precariousness and vulnerability, and instead empower them to make decisions and assert their rights on an equal basis with non-migrant workers in non-agricultural sectors.

COVID-19 has created an unprecedented urgency to address these longrecognized structural barriers, but it has also potentially forged unprecedented opportunities for change. The renewed understanding of the effect of current policies and recognition of SAWP workers as essential rather than merely "low-skilled" workers may present an opportunity for advocates to push for the meaningful structural change that is long overdue. As Mexico's consul general in Vancouver recognized, "we don't need to have another kind of pandemic to act and to recognize the human rights of workers." 188

${ }^{188}$ Labbé, supra note 73. 